\title{
Use of Cerebral Oximetry in Elective Cesarean Section Procedures Performed Under Spinal Anesthesia: A Randomized Prospective Study
}

\author{
Spinal Anestezi ile Yapılan Elektif Sezaryen Vakalarında Serebral Oksimetre \\ Kullanımı: Randomize Prospektif Çalışma \\ ๑ Tuğba Onur, ๑ Ümran Karaca, ๑ Melek Güra Çelik* \\ University of Health Sciences Turkey, Bursa Training and Research Hospital, Clinic of Anesthesiology and Reanimation, Bursa, Turkey \\ *Medeniyet University Goztepe Training and Research Hospital, Clinic of Anesthesiology and Reanimation, Istanbul, Turkey
}

\section{Abstract}

\begin{abstract}
Aim: To compare the effect of bupivacaine and bupivacaine/ fentanyl combination on cerebral oxygenation values with the Near-infrared spectroscopy (NIRS) technique in elective cesarean sections performed under spinal anesthesia.
\end{abstract}

Methods: Fifty patients who underwent cesarean section under spinal anesthesia were randomly divided into two groups. 7.5$10 \mathrm{mg} 0.5 \%$ hyperbaric bupivacaine was administered to the bupivacaine group $(n=25)$ and $7.5-10 \mathrm{mg} 0.5 \%$ hyperbaric bupivacaine+20-25 mcg fentanyl was given to the combination group $(n=25)$. Heart rate, mean arterial pressure, peripheral oxygen saturation, mean values of regional cerebral oxygen saturation after spinal anesthesia were recorded preoperatively and the $1^{\text {st }}, 5^{\text {th }}, 10^{\text {th }}, 15^{\text {th }}$ and $20^{\text {th }}$ minutes after anesthesia. The presence of perioperative nausea and vomiting was assessed with the Verbal Descriptive Scale.

Results: Significant difference was observed in mean arterial pressure values between groups $(p=0.001)$. There was a statistically significant change in cerebral oxygenation values during surgery in both groups $(p=0.001)$. The frequency of nausea and vomiting was lower in the combination group ( $p=0.009)$.

Conclusion: The non-invasive NIRS technique can be safely applied in the monitoring of cerebral oxygenation and hemodynamics in elective cesarean section procedures undergoing spinal anesthesia.

Keywords: Pregnancy, sesarean section, spinal anesthesia, cerebral oxygenation, intraoperative monitoring, near-infrared spectroscopy.
Öz

Amaç: Spinal anestezi ile yapılan elektif sezaryen vakalarında bupivakain ve bupivakain/fentanil kombinasyonunun serebral oksijenizasyon değerlerine etkisini Near-infrared Spektroskopi (NIRS) tekniği ile karşılaştırmak.

Yöntemler: Spinal anestezi ile sezaryen operasyonu olan 50 hasta rastgele yöntemle iki gruba ayrıldı. Hastalardan bupivakain grubuna ( $n=25$ ) 7,5-10 mg \%0,5 hiperbarik bupivakain ve kombine grubuna ( $\mathrm{n}=25$ ) 7,5-10 mg \%0,5 hiperbarik bupivakain+20-25 mcg fentanil uygulandı. Hastaların, spinal anestezi uygulaması sonrası kalp atım hızı, ortalama arteriyel basıncı, periferik oksijen satürasyonu, rejyonel serebral oksijen satürasyonunun ortalama değerleri preoperatif ve anestezi uygulamasının 1, 5, 10, 15, 20 dk sonrasında kaydedildi. Peroperatif bulantı kusma varlığı Verbal Deskriptif Skala ile takip edildi.

Bulgular: Her iki grupta ortalama arter basıncı değerleri arasında anlamlı değişim gözlendi ( $p=0,001)$. Gruplarda cerrahi süresince serebral oksijenizasyon değerleri arasında istatistiksel olarak anlamlı değişim oldu ( $p=0,001)$. Kombine grupta bulantı-kusma görülme sıklığı daha az saptandı $(p=0,009)$.

Sonuç: Spinal anestezi uygulanan elektif sezaryen vakalarında serebral oksijenizasyon ve hemodinami takibinde girişimsel olmayan NIRS tekniği güvenle uygulanabilir.

Anahtar Sözcükler: Gebelik, sezaryen yöntemi, spinal anestezi, serebral oksijenasyon, intraoperatif izleme, yakın kızıl ötesi spektroskopi
Address for Correspondence/Yazışma Adresi: Tuğba Onur, Bursa Training and Research Hospital Clinic of Anesthesiology and Reanimation, Ankara, Turkey E-mail: doktor-t@hotmail.com ORCID: orcid.org/0000-0002-5080-4555 Received/Geliş Tarihi: 18.10.2020 Accepted/Kabul Tarihi: 11.01.2021
${ }^{\circ}$ Copyright 2021 by The Medical Bulletin of istanbul Haseki Training and Research Hospital The Medical Bulletin of Haseki published by Galenos Yayınevi. ${ }^{\circ}$ Telif Hakkı 2021 istanbul Haseki Eğitim ve Araştırma Hastanesi Haseki Tıp Bülteni, Galenos Yayınevi tarafından yayınlanmıştır. 


\section{Introduction}

Cesarean delivery, which is becoming increasingly common worldwide, should have a frequency of around $10-15 \%$ of births; however, its use is rapidly increasing, especially in developing countries (1). In our country, the frequency of cesarean section reached $53.1 \%$ in 2016 (2). Spinal anesthesia for cesarean section has various advantages over general anesthesia, such as the lack of influence on mental functions, continuation of spontaneous breathing, enabling the patient to stay awake, reductions in thromboembolic complications and blood loss, early mobilization, and shortening the duration of hospitalization. In spinal anesthesia, local anesthetics are used either alone or in combination with adjuvant compounds. The most commonly used adjuvant agents are opioids. The addition of opioids to local anesthetics decreases the dose of local anesthetic required, the incidence of side effects on the central nervous system and cardiovascular system, while also shortening the onset of anesthetic action (3-5).

Non-invasive Near-infrared spectroscopy (NIRS) devices, such as the INVOS (Covidien, Somanetics, Troy, MI) device, can be used to measure the saturation of critical watershed areas in which circulation consists of a mixture of $1 / 3$ arterial and $2 / 3$ venous blood (6). In recent years, non-invasive NIRS has also begun to be widely used in surgeries wherein regional anesthesia is applied (7).

In our study, we aimed to compare intrathecal hyperbaric bupivacaine and intrathecal hyperbaric bupivacaine with fentanyl adjuvant in patients undergoing elective caesarean section, with regard to their effects on hemodynamic parameters and cerebral oxygenation values during surgery.

\section{Methods}

\section{Study Design}

Fifty patients between the ages of 18-40 years who underwent caesarean section with spinal anesthesia between 01.08.2013 and 31.12.2013 were included in our study. The ethical approval for the study was obtained from the local ethics committee (decision protocol number: 2013/0037), and informed consent was obtained from each patient included in the study. The patients were randomly divided into 2 groups with the closed envelope technique: those that received 7.5$10 \mathrm{mg} 0.5 \%$ hyperbaric bupivacaine (bupivacaine group, $\mathrm{n}=25$ ) and those that received $7.5-10 \mathrm{mg} 0.5 \%$ hyperbaric bupivacaine $+20-25 \mathrm{mcg}$ fentanyl (combination group, $n=25$ ). The patient exclusion criteria of the study were as follows: refusal of spinal anesthesia administration, presence of bleeding diathesis, determination of infection at the intervention site, having neurological or cardiac comorbidities, documented or suspected allergy to any of the drugs used, history of psychiatric illness, having any type of pregnancy complication (preeclampsia, gestational diabetes, presence of fetal anomaly, etc.), being diagnosed with placenta previa, ablatio placenta or HELLP, and receiving anticoagulant treatment. After the exclusion criteria was applied 74 patients were initially enrolled in the study after signing informed consent forms. However, due to various reasons, such as switching to general anesthesia as a result of unsuccessful spinal anesthesia $(n=6)$, massive bleeding during surgery $(>2000 c c)(n=2)$, development of respiratory depression after spinal block $(n=1)$, and transition to general anesthesia as a result of bowel injury during surgery $(n=1)$, a total of 10 patients were excluded from the study (Figure 1).

The demographic and examination data of the patients (age, weight, height, ASA class, gestational weeks), the average values of heart rate (HR) after spinal anesthesia, mean arterial pressure (MAP), peripheral oxygen saturation $\left(\mathrm{SPO}_{2}\right)$ and the mean values of regional cerebral oxygen saturation $\left(\mathrm{rSO}_{2}\right)$ measured from the right-left hemispheres were recorded preoperatively and the $1^{\text {st }}$, $5^{\text {th }}, 10^{\text {th }}, 15^{\text {th }}$ and $20^{\text {th }}$ minutes after anesthesia. In case the MAP fell below $80 \%$ of baseline value, intravenous (iv) ephedrine (5-10 mg) was administered. The time of first ephedrine administration and total ephedrine amounts were recorded. In case of bradycardia (HR $<50$ beats/ $\mathrm{min})$, iv atropine $0.5 \mathrm{mg}$ was administered. The presence of preoperative nausea and vomiting was assessed with the Verbal Descriptive Scale (VDS) (15) ( $0=$ no nausea, $1=$ mild nausea, $2=$ moderate nausea, $3=$ frequent vomiting, $4=$ severe vomiting).

\section{Spinal Anesthesia Technique}

Before the intervention, $20 \mathrm{~mL} / \mathrm{kg} /$ hour iv crystalloid was administered in 30 minutes, and then spinal anesthesia was performed with a pen-tipped (M. Schilling) $25 \mathrm{G}$ needle from the L3-4 gap in an appropriate position under sterile conditions. Patients were randomly divided into two equallysized groups, the bupivacaine group and the combination group, according to the administered drug ( $s$ ). The bupivacaine group ( $\mathrm{n}=25$ ) was administered $0.5 \%$ hyperbaric bupivacaine 7.5-10 $\mathrm{mg}$ via the intrathecal route, whereas the combination group $(n=)$ was administered fentanyl 20$25 \mathrm{mcg}+0.5 \%$ hyperbaric bupivacaine via the intrathecal route. After the applications, $4 \mathrm{~L} / \mathrm{min}_{2}$ was provided to all patients with a face mask. Pin-prick test was used to evaluate the presence of sensory blockade. Surgery was initiated after reaching a sensory blockade at the T4-T6 level.

\section{The NIRS Technique}

The NIRS device was used to monitor intraparenchymal and microcirculatory oxygenation in the frontal cortex, 


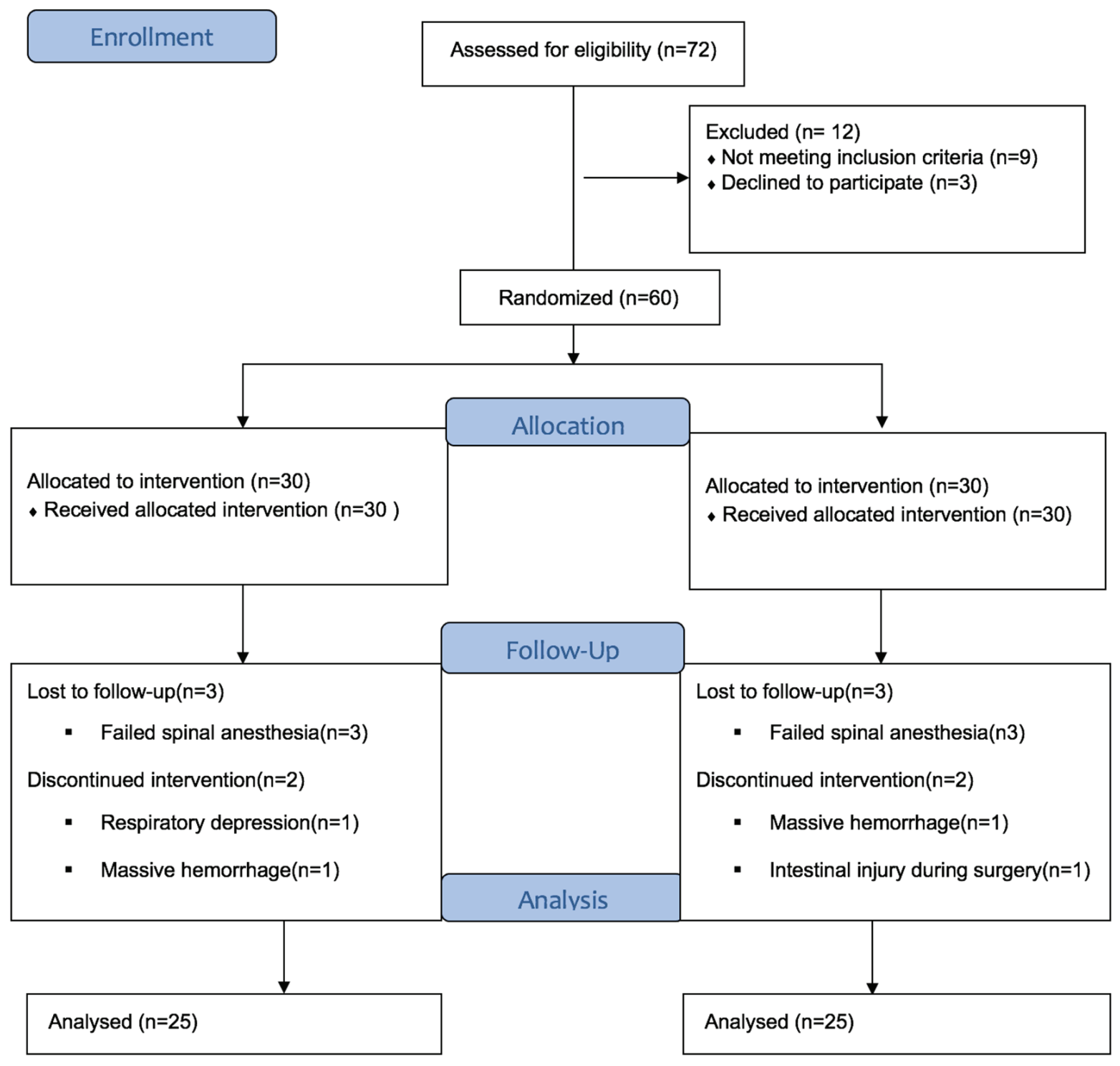

Figure 1. CONSORT 2010 flow diagram

and thereby was utilized as a measure of cerebral tissue oxygenation. The INVOS monitor has a light source and a probe with two photodetectors placed in the right and left anterior hemispheres of the forehead. The photodetector closest to the light source absorbs superficial rays (from skin, bone and fat tissue), while the other photodetector absorbs rays from deep brain tissues. The $\mathrm{rSO}_{2}$ measurement, in which the oxygen saturation values of the right and left hemispheres are expressed in percent (\%), measures the ratio of oxyhemoglobin of the area under the sensor to total hemoglobin based on the difference in the relative transmittance of biological tissue to near infrared light. This ratio is expressed as the percentage value of $\mathrm{rSO}_{2}$. Its reference value ranges from $58 \%$ to $82 \%$ in healthy individuals. During hypoxia, hypocapnia, hypercapnia and arterial hypotension, $\mathrm{rSO}_{2}$ index values change and can be used to assess cerebral oxygenation.

\section{Statistical Analysis}

Data analysis was done using the IBM SPSS 22.0 statistics package program. Quantitative data were presented as mean and standard deviation, and qualitative data were presented as numbers and percentages. For quantitative data, the repeated measures analysis of variance test was used for the temporal comparison of multiple groups, and the independent samples student t-test was used for comparison of the two subject groups. chi-square $\left(X^{2}\right)$ tests were used for the comparison of qualitative data. 


\begin{tabular}{|c|c|c|c|}
\hline & $\begin{array}{l}\text { Group } \\
\text { bupivacaine }\end{array}$ & $\begin{array}{l}\text { Group } \\
\text { combination }\end{array}$ & $\mathbf{p}^{*}$ \\
\hline Age & $29.56 \pm 3.82$ & $29.84 \pm 4.09$ & 0.804 \\
\hline Weight (kg) & $75.72 \pm 8.15$ & $77.6 \pm 6.98$ & 0.385 \\
\hline Height (cm) & $161.6 \pm 3.61$ & $162.32 \pm 5.09$ & 0.556 \\
\hline Gestational week & $38.8 \pm 0.99$ & $39.08 \pm 0.91$ & 0.143 \\
\hline
\end{tabular}

Table 2. Total fluid replacement given in the groups. the amount of ephedrine use. the mean time of first ephedrine administration and the number of patients administered ephedrine within the group ( $n$ : mean \pm SD)

\begin{tabular}{|l|l|l|l|}
\hline & $\begin{array}{l}\text { Group } \\
\text { bupivacaine }\end{array}$ & $\begin{array}{l}\text { Group } \\
\text { combination }\end{array}$ & $\mathbf{p}^{*}$ \\
\hline $\begin{array}{l}\text { Total fluid replacement } \\
\text { (Crystalloid) (ml) }\end{array}$ & $1352 \pm 82.26$ & $1368 \pm 69.04$ & 0.460 \\
\hline $\begin{array}{l}\text { Amount of ephedrine } \\
\text { used (mg) }\end{array}$ & $10 \pm 4.08$ & $9 \pm 2.11$ & 0.501 \\
\hline $\begin{array}{l}\text { Time of first ephedrine } \\
\text { administration (min) }\end{array}$ & $7.30 \pm 4.79$ & $7.19 \pm 4.77$ & 0.955 \\
\hline $\begin{array}{l}\text { Number of patients that } \\
\text { received ephedrine (n) }\end{array}$ & 10 & 11 & 0.774 \\
\hline *Student t-test SD: Standart deviation & \multicolumn{3}{|l}{} \\
\hline
\end{tabular}

The Spearman rho correlation coefficient was calculated to analyze correlations. Analysis results with a probability (P) a less than 0.05 were accepted as significant, whereas higher values were accepted to be insignificant.

\section{Results}

There were no differences between the two groups in terms of age, weight, height, gestational week, total fluid replacement, amount of ephedrine use, time of first ephedrine administration, and $\mathrm{SPO}_{2}$ values (Table 1-3). All patients were accepted as ASA II. Ephedrine administration was needed at an average of 7-8 minutes after spinal anesthesia. An average of $10 \mathrm{mg}$ of ephedrine was administered to 10 patients in the bupivacaine group and to 11 patients in the combination group.

MAP and HR values of the groups are shown in Table 3. In both groups, the initial MAP values were found to be higher than all other values during surgery $(p=0.001)$, the MAP values recorded during skin incision were higher than the MAP values recorded at the $5^{\text {th }}$ minute after the skin incision in both groups ( $p=0.048, p=0.012$ ).

There was a statistically significant change in $\mathrm{rSO}_{2}$ values recorded during surgery in both groups $(p=0.001)$. The decrease in $\mathrm{rSO}_{2}$ values (compared to baseline) during skin incision, at the $5^{\text {th }}$ minute after incision, and at the moment of delivery were statistically significant $(p<0.001)$. There was no significant difference between the two groups in terms of $\mathrm{rSO}_{2}$ values recorded during surgery ( $p>0.05$, Table 3).

A significant difference in VDS values between measurement time-points during the surgery was identified in the bupivacaine group $(p=0.009)$; however, there was no significant difference in the combination group ( $p=0.108)$. The VDS values of the bupivacaine group at the $5^{\text {th }}$ minute after skin incision and at the moment of baby delivery were found to be higher than the respective values of the combination group $(p=0.027$ and $p=0.003$, respectively; Table 3).

Correlation analyses revealed weak positive correlations between $\mathrm{rSO}_{2}$ and MAP values measured at the time of skin incision ( $r=0.326 ; p=0.021)$, at the $5^{\text {th }}$ minute after skin incision $(r=0.326 ; p=0.021)$, and at the $5^{\text {th }}$ minute after baby delivery $(r=0.352 ; p=0.012)$ (Table 4$)$.

\section{Discussion}

In our study, we compared a group receiving hyperbaric bupivacaine to a group in which fentanyl was added to hyperbaric bupivacaine, in terms of cerebral oxygenation and various other characteristics. Although significant decreases were observed in $\mathrm{rSO}_{2}$ according to baseline values in both groups (until baby delivery), $\mathrm{rSO}_{2}$ values were similar between the groups. Ephedrine was generally required in the first 10 minutes of surgery in both groups. The incidence of nausea and vomiting was lower in the combination group.

Hypotension is the most common complication after spinal anesthesia (8). Hypotension should not be allowed to develop during caesarean section, as it may cause changes in the physiology of both the new-born and the mother. Since hemodynamic instability and hypotension may develop rather frequently in relation with the use of local anesthetics during spinal anesthesia, opioid addition has emerged as a reliable method to prevent such occurrences (9). In addition, it is known that the combination of opioids with local anesthetics shortens the onset time of sensory and motor block, and facilitates more effective and long-term anesthesia (10). There is no definite instruction regarding the intrathecal dose of local anesthetics and opioids. The lowest effective fentanyl dose reported to be used in caesarean section is $6.25 \mathrm{mcg}(11)$. There are studies suggesting that $20-30 \mathrm{mcg}$ of fentanyl should be added to bupivacaine $(12,13)$. Kang et al. (14) compared the combination of $8 \mathrm{mg} 0.5 \%$ hyperbaric bupivacaine and $5 \mathrm{mg} \mathrm{0.5 \%}$ hyperbaric bupivacaine with 25 mcg fentanyl, and showed that the combination of bupivacaine and fentanyl provided better hemodynamic stability. Meyer et al. (15) studied patients who underwent spinal anesthesia in caesarean section procedures by forming two groups according to drug administration 
Table 3. Comparison of $\mathrm{HR}, \mathrm{MAP}, \mathrm{SpO}_{2}, \mathrm{rSO}_{2}$, VDS values of the groups during surgery (mean $\pm \mathrm{SD}$ )

\begin{tabular}{|c|c|c|c|c|c|c|c|c|c|}
\hline & & T0 & T1 & T2 & T3 & T4 & T5 & T6 & p-value \\
\hline $\mathrm{HR}$ & $\begin{array}{l}\text { Bupivacaine } \\
\text { group } \\
\text { Combination } \\
\text { group } \\
\mathrm{p}^{\star}\end{array}$ & $\begin{array}{l}92.36 \pm 9.53 \\
93.2 \pm 13.03 \\
0.79\end{array}$ & $\begin{array}{l}98.28 \pm 17.24 \\
96 \pm 18.63 \\
0.65\end{array}$ & $\begin{array}{l}99.76 \pm 19.56 \\
95.76 \pm 19.08 \\
0.46\end{array}$ & $\begin{array}{l}98.86 \pm 18.45 \\
98.28 \pm 16.08 \\
0.71\end{array}$ & $\begin{array}{l}105 \pm 19.46 \\
99 \pm 15.63 \\
0.23\end{array}$ & $\begin{array}{l}96.32 \pm 14.7 \\
94.8 \pm 14.86 \\
0.71\end{array}$ & $\begin{array}{l}95.48 \pm 18.18 \\
91.43 \pm 13.2 \\
0.37\end{array}$ & $\begin{array}{l}p>0.05 \\
p>0.05\end{array}$ \\
\hline MAP & $\begin{array}{l}\text { Bupivacaine } \\
\text { group } \\
\text { Combination } \\
\text { group } \\
\mathrm{p}^{*}\end{array}$ & $\begin{array}{l}92.72 \pm 11.83 \\
91.4 \pm 10.48 \\
0.67\end{array}$ & $\begin{array}{l}82.48 \pm 14.79 \\
82.56 \pm 12.43 \\
0.98\end{array}$ & $\begin{array}{l}77.72 \pm 15.19 \\
75.8 \pm 12.52 \\
0.62\end{array}$ & $\begin{array}{l}80.08 \pm 19.35 \\
81 \pm 13.59 \\
0.84\end{array}$ & $\begin{array}{l}79.12 \pm 12.2 \\
81 \pm 11.39 \\
0.68\end{array}$ & $\begin{array}{l}80.96 \pm 7.86 \\
81 \pm 11.39 \\
0.98\end{array}$ & $\begin{array}{l}81.92 \pm 9 \\
78.92 \pm 10.09 \\
0.27\end{array}$ & $\begin{array}{l}T 1-T 2 p=0.048 \\
\text { Other } p>0.05 \\
\text { T1-T2 } p=0.012 \\
\text { Other } p>0.05\end{array}$ \\
\hline $\mathrm{SpO}_{2}$ & $\begin{array}{l}\text { Bupivacaine } \\
\text { group } \\
\text { Combination } \\
\text { group } \\
p^{*}\end{array}$ & $\begin{array}{l}99 \pm 1.08 \\
98.96 \pm 0.79 \\
0.88\end{array}$ & $\begin{array}{l}99.16 \pm 0.75 \\
98.92 \pm 1.22 \\
0.41\end{array}$ & $\begin{array}{l}98.8 \pm 0.96 \\
99.44 \pm 0.94 \\
0.18\end{array}$ & $\begin{array}{l}98.96 \pm 1.24 \\
99.44 \pm 0.65 \\
0.09\end{array}$ & $\begin{array}{l}99.32 \pm 0.75 \\
99.28 \pm 1.02 \\
0.87\end{array}$ & $\begin{array}{l}99.6 \pm 0.58 \\
99.4 \pm 0.76 \\
0.31\end{array}$ & $\begin{array}{l}99.56 \pm 0.58 \\
99.36 \pm 0.76 \\
0.32\end{array}$ & $\begin{array}{l}p>0.05 \\
p>0.05\end{array}$ \\
\hline $\mathrm{rSO}_{2}$ & $\begin{array}{l}\text { Bupivacaine } \\
\text { group } \\
\text { Combination } \\
\text { group } \\
p^{\star}\end{array}$ & $\begin{array}{l}63.84 \pm 7.96 \\
65.12 \pm 6.46 \\
0.53\end{array}$ & $\begin{array}{l}60.4 \pm 8.04 \\
61.32 \pm 6.54 \\
0.65\end{array}$ & $\begin{array}{l}59.52 \pm 9.36 \\
59.32 \pm 8.8 \\
0.93\end{array}$ & $\begin{array}{l}60.16 \pm 9.36 \\
60.24 \pm 7.76 \\
0.97\end{array}$ & $\begin{array}{l}66.64 \pm 8.25 \\
66.96 \pm 9.8 \\
0.91\end{array}$ & $\begin{array}{l}65.92 \pm 7.06 \\
66.36 \pm 10.3 \\
0.86\end{array}$ & $\begin{array}{l}67.68 \pm 8.51 \\
66.44 \pm 9.9 \\
0.63\end{array}$ & $\begin{array}{l}\text { T0-T3: } p<0.001 \\
\text { T0-T3: } p<0.001\end{array}$ \\
\hline VDS & $\begin{array}{l}\text { Bupivacaine } \\
\text { group } \\
\text { Combination } \\
\text { group } \\
p^{*}\end{array}$ & $\begin{array}{l}- \\
- \\
-\end{array}$ & $\begin{array}{l}0.12 \pm 0.33 \\
0.12 \pm 0.33 \\
1\end{array}$ & $\begin{array}{l}0.28 \pm 0.61 \\
- \\
0.027\end{array}$ & $\begin{array}{l}0.44 \pm 0.71 \\
- \\
0.003\end{array}$ & $\begin{array}{l}0.36 \pm 0.57 \\
0.16 \pm 0.47 \\
0.18\end{array}$ & $\begin{array}{l}0.24 \pm 0.66 \\
0.12 \pm 0.33 \\
0.42\end{array}$ & $\begin{array}{l}0.08 \pm 0.28 \\
0.04 \pm 0.2 \\
0.56\end{array}$ & $\begin{array}{l}p=0.009 \\
p>0.05\end{array}$ \\
\hline
\end{tabular}

*Student-t test, ${ }^{*}$ SStudent-t test, HR: Heart rate, MAP: Mean artery pressure, $\mathrm{SpO}_{2}$ : Peripheral oxygen saturation $\mathrm{rSO}_{2}$ : Cerebral oxygen saturation, VDS: Verbal descriptive scales. T0: anesthesia onset, T1: Skin incision, T2: $5^{\text {th }}$ minute after skin incision, T3: Moment of baby delivery, T4: $5^{\text {th }}$ minute after baby delivery, T5: $10^{\text {th }}$ minute after baby delivery, T6: $20^{\text {th }}$ minute after baby delivery

\section{Table 4. Correlation of rSO2 and MAP values of groups}

\begin{tabular}{|c|c|c|c|c|c|c|c|c|c|}
\hline & & & $\mathrm{rSO}_{2}$ & & & & & & \\
\hline & & & TO & T1 & T2 & T3 & T4 & T5 & T6 \\
\hline & TO & $r$ & 0.067 & & & & & & \\
\hline & 10 & $p$ & 0.645 & & & & & & \\
\hline & $T_{1}$ & $r$ & & 0.370 & & & & & \\
\hline & 11 & $p$ & & $0.008^{*}$ & & & & & \\
\hline & בT & $r$ & & & 0.326 & & & & \\
\hline & 12 & $p$ & & & $0.021^{*}$ & & & & \\
\hline 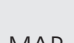 & $T_{2}$ & $r$ & & & & 0.128 & & & \\
\hline TVIAT & ST & $p$ & & & & 0.376 & & & \\
\hline & T1 & $r$ & & & & & 0.352 & & \\
\hline & & $p$ & & & & & $0.012^{*}$ & & \\
\hline & T5 & $r$ & & & & & & 0.26 & \\
\hline & J & $p$ & & & & & & 0.068 & \\
\hline & Th & $r$ & & & & & & & 0.229 \\
\hline & & $p$ & & & & & & & 0.110 \\
\hline
\end{tabular}

(15 mg bupivacaine and $12 \mathrm{mg}$ bupivacaine+15 mcg fentanyl), similar to our study design. While there was no difference between blockade characteristics between the groups, they found that the incidence of nausea/vomiting 
and hypotension were more common in the bupivacaine group (15). In our study, while nausea and vomiting were also found to be more common in recipients of bupivacaine only, no difference was observed between the groups according to hemodynamic parameters. In both groups, the lowest MAP was seen at the time of delivery and during the first 5 minutes following delivery. This situation has been associated with sympathetic blockade in relation with the use of spinal anesthesia. The sensory block in both groups was at the T4-T6 level, and the average time it took to develop adequate block was 3.5-4.5 minutes. Phenylephrine and ephedrine are routinely administered to increase MAP and cerebral perfusion in anesthesia-related hypotension that develops during perioperative processes (16). Since ephedrine is an agent with positive chronotropic and inotropic effects, it has become the preferred agent in hypotension that develops during regional anesthesia (17). In our study, the frequency and amount of ephedrine administration and hemodynamic responses were found to be similar in both groups. $\mathrm{rSO}_{2}$ reflects the balance between cerebral oxygen delivery and oxygen requirements, is affected by changes in blood oxygenation, cerebral blood flow, hemoglobin concentration and cerebral metabolism. Cerebral oximetry, which is widely used in neurosurgery and cardiovascular surgery because it provides critical information pertaining to the oxygenation level in cerebral tissue, is recently being used in surgeries where regional anesthesia is applied. A previous study reported a 5\% decrease in $\mathrm{rSO}_{2}$ value compared to baseline with NIRS-based measurements in 38 patients who underwent caesarean section under spinal anesthesia (18). The sensitivity of the NIRS technique to predict hypotension in caesarean sections performed with the use of spinal anesthesia was determined to be $100 \%$ and the specificity was $85 \%$. The study by Fassoulaki et al. (19) reported $\mathrm{rSO}_{2}$ changes during the operation in 35 pregnant women undergoing elective caesarean section with spinal anesthesia. In the study, $1.8-2 \mathrm{~mL} 0.75 \%$ ropivacaine $+10 \mathrm{mcg}$ fentanyl were administered intrathecally to the patients. In about half of the patients, especially in the $5^{\text {th }}$ and $10^{\text {th }}$ minutes after spinal anesthesia administration, a decrease in $\mathrm{rSO}_{2}$ values from $65 \%$ (baseline) to $55 \%$ was observed, and it was stated that the clinical effects of these decreases could be investigated in detail in the long term. In another study, 42 patients who underwent caesarean section were divided into two groups as isobaric bupivacaine recipients and hyperbaric bupivacaine recipients and the effects on $\mathrm{rSO}_{2}$ were compared. It was concluded that hemodynamic parameters remained stable and cerebral oxygenation was preserved in the group receiving isobaric bupivacaine (20). Kaori Yamazaki et al. (21) recorded perioperative
$\mathrm{rSO}_{2}$ values of 18 pregnant women who underwent caesarean section. In patients with placenta previa or massive bleeding, $\mathrm{rSO}_{2}$ rapidly decreased from $67.2 \%$ to $54.2 \%$, while there was no change in $\mathrm{sPO}_{2}$ measured simultaneously. In the same study, the average $\mathrm{rSO}_{2}$ before induction in pregnant women with preeclampsia was found to be significantly higher than normotensive women. In the study conducted by Van Noord et al. (22), while a decrease in MAP was observed in $19.5 \%$ of patients who were scheduled for general anesthesia and had undergone surgery with controlled hypotension due to major bleeding, the $\mathrm{rSO}_{2}$ decrease was measured as $21.5 \%$ on the left and $14.7 \%$ on the right. Hypotension and cerebral desaturation were observed in the transition to a semi-sitting position in $42 \%$ of shoulder arthroscopy cases in which the risk of developing hypotension was increased due to surgical position (23). In a study involving patients undergoing shoulder surgery, a decrease in cerebral oxygenation associated with controlled hypotension was identified together with a decrease in cerebral blood flow in simultaneous Doppler measurements; however, the $\mathrm{SPO}_{2}$ values of these patients had not demonstrated any significant change throughout surgery (24). Similarly, in our study, a decrease in $\mathrm{rSO}_{2}$ values was found to be associated with a decrease in MAP values, especially in the measurement time-points with sympathetic blockade. The absence of simultaneous $\mathrm{sPO}_{2}$ changes indicates that cerebral oximetry monitoring is more sensitive than $\mathrm{SPO}_{2}$ monitoring, especially when it is considered that cerebral oxygenation level is critical in such surgeries.

Ephedrine was administered to prevent the decrease in cerebral perfusion associated with hypotension in patients whose right-left $\mathrm{rSO}_{2}$ average fell below $50 \%$. In a study conducted in patients undergoing cardiac surgery, there was observational evidence that decreased intraoperative and preoperative cerebral oximetry levels gave an idea of poor postoperative outcomes, and that intra-operatively decreased cerebral oximetry levels could be reversed by interventions aimed at optimizing cerebral oxygenation (25). Especially in patients with increased risk for hypotension, such as pregnant women, those undergoing surgeries requiring non-supine positioning, patients with advanced age, those with risks for bleeding, and individuals undergoing cardiac surgery, cerebral oximetry measurements may be crucial in terms of enabling timely intervention(s) to prevent reduced cerebral perfusion.

\section{Study Limitations}

Since we did not measure the amount of fluids administered before and after surgery and the amount of urine output, we could not analyze our data with regard to these variables, indicating a limitation in the assessment 
of overall hemodynamic stability of the patients. Secondly, our study was conducted on a small number of patients due to financial limitations that affected the number of patients that could be included enrolled. Lastly, the effect of hypotension and $\mathrm{rSO}_{2}$ reduction on cognitive functions were not assessed in the postoperative period. Future studies would benefit from including a higher number of patients.

\section{Conclusion}

We think that cerebral oximetry can be used as an effective and reliable perioperative method of monitoring in patients undergoing cesarean section with spinal anesthesia, especially in cases with a high probability of developing hypotension.

\section{Authorship Contributions}

Concept: M.G.Ç., T.O., Design: T.O., M.G.Ç., Data Collection or Processing: T.O., Analysis or Interpretation: T.O., Literature Search: T.O., Ü.K., Writing: T.O., Ü.K.

Conflict of Interest: No conflict of interest was declared by the authors.

Financial Disclosure: The authors declared that this study received no financial support.

\section{References}

1. Betrán AP, Ye J, Moller AB, Zhang J, Gülmezoglu AM, Torloni MR. The Increasing Trend in Caesarean Section Rates: Global, Regional and National Estimates: 1990-2014. PLoS One. 2016;11:0148343.

2. T.C. Sağlık Bakanlığı Sağlık i̇statistikleri Yıllığı 2016. Available from: https://dosyasb.saglik.gov.tr/ Eklenti/13160,sy2016enpdf.pdf?0 Ankara; 2017

3. Braga AA, Frias JA, Braga FS, Potério GB, Hirata ES, Torres NA. Spinal anesthesia for cesarean section. Use of hyperbaric bupivacaine (10mg) combined with different adjuvants. Rev Bras Anestesiol 2012;62:775-87.

4. Venkata HG, Pasupuleti S, Pabba UG, Porika S, Talari G. A randomized controlled prospective study comparing a low dose bupivacaine and fentanyl mixture to a conventional dose of hyperbaric bupivacaine for cesarean section. Saudi J Anaesth 2015;9:122-7.

5. Gajbhare MKN, Kamble NP. Comparative study of intrathecal bupivacaine versus bupivacaine with fentanyl for cesarean section. Hint J Clin Anaesth 2016;3:271-7.

6. Brodsky JB. What intraoperative monitoring makes sense? Chest 1999;115:101-5.

7. Hoppenstein D, Zohar E, Ramaty E, Shabat S, Fredman B. The effects of general vs spinal anesthesia on frontal cerebral oxygen saturation in geriatric patients undergoing emergency surgical fixation of the neck of femur. J Clin Anesth 2005;17:431-8.
8. Mercier FJ, Augè M, Hoffmann C, Fischer C, Le Gouez A. Maternal hypotension during spinal anesthesia for caesarean delivery. Minerva Anestesiol 2013;79:62-73.

9. Kirson LE, Goldman JM, Slover RB. Low-dose intrathecal morphine for postoperative pain control in patients undergoing transurethral resection of the prostate. Anesthesiology 1989;71:192-5.

10. F Farzi, Bir Mirmansouri, BN Nabi, et al. Comparing the Effect of Adding Fentanyl, Sufentanil, and Placebo with Intrathecal Bupivacaine on Duration of Analgesia and Complications of Spinal Anesthesia in Patients Undergoing Cesarean Section. Anesth Pain Med 2017;7:127-38.

11. Hunt CO, Naulty JS, Bader AM, et al. Perioperative analgesia with subarachnoid fentanyl-bupivacaine for cesarean delivery. Anesthesiology 1989;71:535-40.

12. Hamber EA, Viscomi CM. Intrathecal lipophilic opioids as adjuncts to surgical spinal anesthesia. Reg Anesth Pain Med 1999;24:255-63.

13. Palmer CM, Cork RC, Hays R, Van Maren G, Alves D. The doseresponse relation of intrathecal fentanyl for labor analgesia. Anesthesiology 1998;88:355-61.

14. Kang FC, Tsai YC, Chang PJ, Chen TY. Subarachnoid fentanyl with diluted small-dose bupivacaine for cesarean section delivery. Acta Anaesthesiol Sin 1998;36:207-14.

15. Meyer RA, Macarthur AJ, Downey K. Study of equivalence: spinal bupivacaine $15 \mathrm{mg}$ versus bupivacaine $12 \mathrm{mg}$ with fentanyl $15 \mu \mathrm{g}$ for cesarean delivery. Int J Obstet Anesth 2012;21:17-23.

16. Prakash S, Pramanik V, Chellani H, Salhan S, Gogia AR. Maternal and neonatal effects of bolus administration of ephedrine and phenylephrine during spinal anaesthesia for caesarean delivery: a randomised study. Int J Obstet Anesth 2010;19:24-30.

17. Şahin \$̧, Günaydin B, Özkan ST. Santral Blokların Komplikasyonları. Doğumda Analjezi Sezaryende Anestezi. Available from: https://www.tard.org.tr/assets/kilavuz/9.pdf Bursa, Medyay Kitabevi 2019;117-36.

18. Berlac PA, Rasmussen YH. Per-operative cerebral near-infrared spectroscopy (NIRS) predicts maternal hypotension during elective caesarean delivery in spinal anaesthesia. Int J Obstet Anesth 2005;14:26-31.

19. Fassoulaki A, Paraskeva A, Tsaroucha A. Cesarean delivery under spinal anesthesia is associated with decreases in cerebral oxygen saturation as assessed by NIRS: an observational study. Curr Med Res Opin 2014;30:331-7.

20. Kondo Y, Sakatani K, Hirose N, et al. Effect of spinal anesthesia for elective cesarean section on cerebral blood oxygenation changes: comparison of hyperbaric and isobaric bupivacaine. Adv Exp Med Biol 2013;765:109-14.

21. Yamazaki K, Suzuki K, Itoh $\mathrm{H}$, et al. Cerebral oxygen saturation evaluated by near-infrared time-resolved spectroscopy (TRS) 
in pregnant women during caesarean section - a promising new method of maternal monitoring. Clin Physiol Funct Imaging 2013;33:109-16.

22. Van Noord BA, Stalker CL, Roffey P, Thangathurai D. The use of regional cerebral oximetry monitoring during controlled hypotension: a case series. J Clin Monit Comput 2014;28:31923.

23. Chan JH, Perez H, Lee H, Saltzman M, Marra G. Evaluation of cerebral oxygen perfusion during shoulder arthroplasty performed in the semi-beach chair position. J Shoulder Elbow Surg 2020;29:79-85.

24. Aguirre JA, Etzensperger $F$, Brada $M$, et al. The beach chair position for shoulder surgery in intravenous general anesthesia and controlled hypotension: Impact on cerebral oxygenation, cerebral blood flow and neurobehavioral outcome. J Clin Anesth 2019;53:40-8.

25. Kunst G, Milan Z. Cerebral oximetry: another blow to noninvasive monitoring? Anaesthesia 2017;72:1435-8. 